\title{
Novel Plasmids Responsible for the Cellulose Utilizing Ability of Ruminococcus albus
}

\author{
Kunio Ohmiya, Chieko Hoshino and Shoichi Shimizu \\ School of Agriculture, Nagoya University, \\ Nagoya-shi 464-01
}

(Received December 15, 1989)

\begin{abstract}
Two novel plasmids were isolated from Ruminococcus albus and named as $\mathrm{pRAB}$ and $\mathrm{pRAC}$. Both were isolated from the bacterium acclimated on an anaerobic medium containing ball-milled cellulose (BMC) as a main carbon source. When the bacterium was acclimated on cellobiose containing medium, pRAB $(7.4 \mathrm{kbp})$ remarkably decreased while $\mathrm{pRAC}(15.3 \mathrm{kbp})$ remained, suggesting that $\mathrm{pRAB}$ requires $\mathrm{BMC}$ as a selection pressure. The Pst I site on the HI fragment of pRAC prepared from BMC containing culture broth was cleaved by the restriction enzyme with more difficulty, compared with the site of $\mathrm{pRAC}$ prepared from cellobiose containing culture broth. These data suggest that both plasmids are responsible for the cellulose utilization ability of $R$. albus.
\end{abstract}

Jpn. J. Zootech. Sci., 61 (6) : 557-561, 1990

Key words : plasmid, cellulose, Ruminococcus albus

Ruminococcus albus, a rumen anaerobe, is known to be a potent cellulolytic bacterium dominant in the rumen of cattle. The cow supplies us with many economically important materials (such as meat, milk and leather) through bioconversion of inexpensive lignocellulosic feedstuff, mainly grass. One of the growth-limiting factors of cattle is considered to be the lignocellulose degrading rate of rumen microorganisms. We have previously studied the cellulolytic properties of $R$. albus, in vitro $^{1-4)}$, and its cellulases ${ }^{5-7)}$. In addition, we also investigated the degradation of lignin related compounds $\mathrm{s}^{8-12)}$ and cellulose ${ }^{13-16)}$ by the other rumen anaerobes. We studied the enhancement of lignocellulose degradation using gene technology such as cell fusion ${ }^{17-22)}$ and gene cloning ${ }^{23-25)}$. During the course of our research, we have often noticed the sudden loss of the cellulolytic activity of $R$. albus depending on cultivation conditions such as the presence or absence of insoluble cellulose in the medium. This suggested the presence of plasmids in $R$. albus associated with cellulose degradation. CHAMPION et al. ${ }^{26)}$ and ASMUNDSON and KELLY ${ }^{27)}$ previously reported the presence of some cryptic plasmids. However, up to now little is known about $R$. albus plasmids. This study describes the isolation and characterization of two plasmids in $R$. albus.

\section{Materials and Methods}

$R$. albus $\mathrm{F}-40$, isolated from bovine rumen and donated from Tohoku University, was anaerobically cultivated in a synthetic medium containing $1 \%$ ball-milled cellulose (BMC medium), $1 \%$ cellobiose (cellobiose medium) or $1 \%$ glucose (glucose medium) at $\mathrm{pH} 6.8$ and $37^{\circ} \mathrm{C}$ and denoted as $R$, albus $\mathrm{F}-40 \mathrm{~B}, R$, albus $\mathrm{F}-40 \mathrm{C}$ and $R$. albus $\mathrm{F}-40 \mathrm{G}$, respectively. The host strain Escherichia coli HB 101 and a 
plasmid pACYC 184 were used. Transformants were cultivated in Luria-Bertani (LB) broth containing antibiotics at $37^{\circ} \mathrm{C}, \mathrm{pH} 7.5$ under aeration. Plasmids of $R$. albus were isolated by means of the method used by BirnBorm and DoLY ${ }^{28)}$. The final crude preparations were treated with RNase $(25 \mu \mathrm{g} / \mathrm{m} l)$, extracted once with phenol-chloroform $(1: 1)$ and twice with diethylether before precipitation with two volumes of ethanol to obtain the final preparation. Relative concentrations of the isolated plasmids were determined by measuring the density of the bands on the photo-film with a scanning densitometer (DUAL-WAVE LENGTH TLC SCANNER CS-910, SHIMADZU, Kyoto). The isolated plasmids were cleaved with some restriction enzymes for mapping the restriction enzyme sites and ligated into the plasmid pACYC 184 at $16^{\circ} \mathrm{C}$ for $30 \mathrm{~min}$. The chimera plasmids constructed were used for transfor-' ming competent $E$. coli cells. Restriction endonucleases and other manipulation enzymes were purchased from Boehringer Manheim (Tokyo) and Takara Shuzo (Kyoto). The separation and molecular size estimation of plasmids and DNA fragments were performed by electrophoresis with agarose gel $(0.7 \%)$. All these gene manipulations were performed according to the methods described by MANIATIS et $a l{ }^{29)}$.

\section{Results and Discussion}

Growth of $R$. albus on BMC, cellobiose or glucose.

R. albus $\mathrm{F}-40 \mathrm{~B}$ was inoculated into the medium containing BMC, cellobiose or glucose as a main carbon source and anaerobically cultivated for 2 days at $37^{\circ} \mathrm{C}$. The extents of the bacterial growth were measured by the turbidity of the culture broth at $660 \mathrm{~nm}$ (Table 1 , column B), showing that the bacterium grew well on the three carbon sources. $R$. albus $\mathrm{F}-40 \mathrm{C}$ grew rapidly on cellobiose and glucose but slowly on BMC, suggesting that the bacterium partly lost the ability to digest insoluble cellulose (BMC) after adaptation to the soluble cellobiose substrate (Table 1, column C). R. albus F-40G grew in the glucose medium rapidly, grew in the cellobiose medium more slowly than $R$. albus $\mathrm{F}-40 \mathrm{C}$ and grew in the BMC medium much more slowly than $R$. albus $\mathrm{F}-40 \mathrm{~B}$, revealing that the organism partly lost the ability to utilize BMC and had a slightly reduced ability to utilize cellobiose (Table 1, column G).

Isolation of plasmids from $R$. albus.

Plasmid samples B, C and G were prepared from the fresh cells of $R$. albus F-40 B, F-40 C and $\mathrm{F}-40 \mathrm{G}$, respectively. Since only plasmids

Table 1. Growth* of Ruminococcus albus on various carbon sources during 1 day cultivation at $37^{\circ} \mathrm{C}$ and $\mathrm{pH} 6.8$.

\begin{tabular}{lccc}
\hline \multirow{2}{*}{$\begin{array}{l}\text { Main } \\
\text { source }\end{array}$} & \multicolumn{3}{c}{ Ruminococcus albus $\mathrm{F}-40$} \\
\cline { 2 - 4 } & $\mathrm{B}^{* *}$ & $\mathrm{C}^{* *}$ & $\mathrm{G}^{* *}$ \\
\hline BMC & $0.530^{* * *}$ & 0.250 & 0.050 \\
Cellobiose & 2.000 & 2.300 & 1.050 \\
Glucose & 2.400 & 2.400 & 2.200 \\
\hline
\end{tabular}

* Turbidity of whole culture broth at $660 \mathrm{~nm}$

** Names of strains of $R$. albus F-40

*** Turbidity of supernatant only of the settled BMC-culture broth

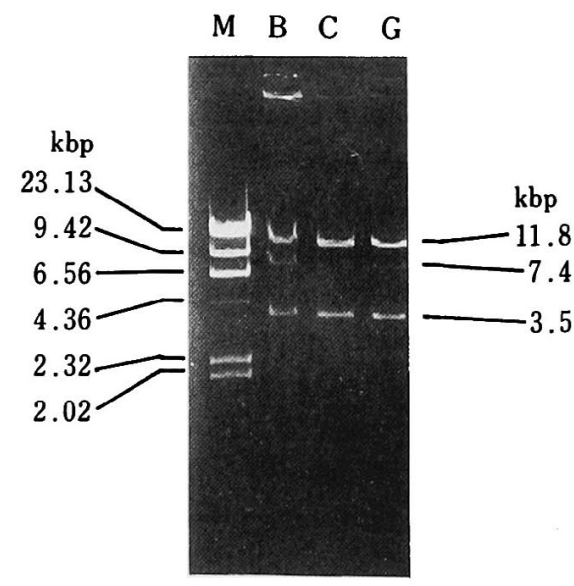

Fig. 1. Agarose-gel electrophoretograms of plasmid samples $\mathrm{B}, \mathrm{C}$ and $\mathrm{G}$ cleaved by BamHI.

Lane M $: \lambda$ DNA cleaved with Hind III (molecular size standards)

Lane B : plasmid sample B cleaved by BamHI

Lane C : plasmid sample $C$ cleaved by BamHI

Lane G : plasmid sample G cleaved by BamHI 


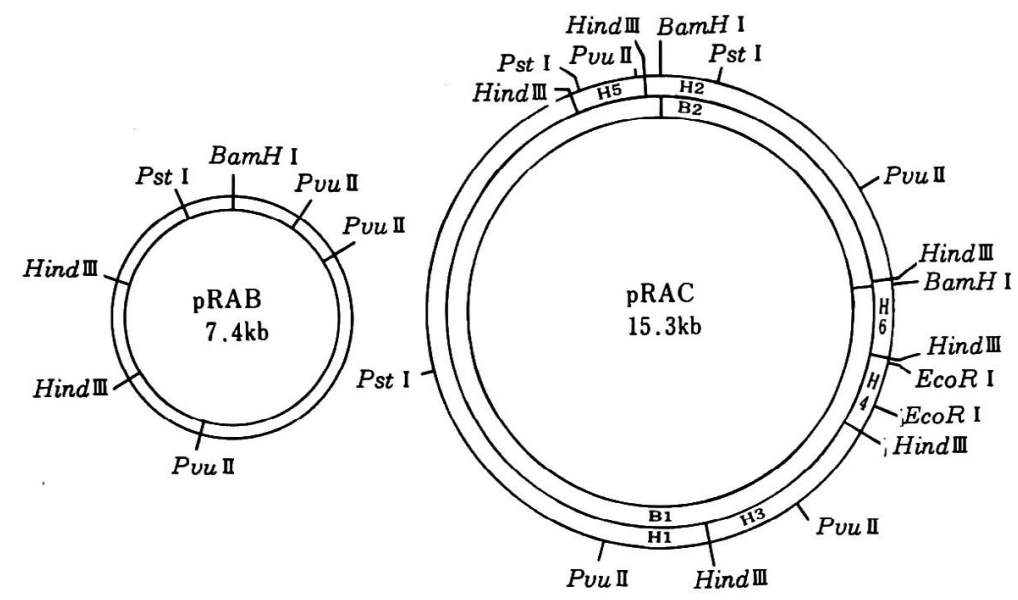

Fig. 2. Restriction maps of $\mathrm{pRAB}$ and $\mathrm{pRAC}$.

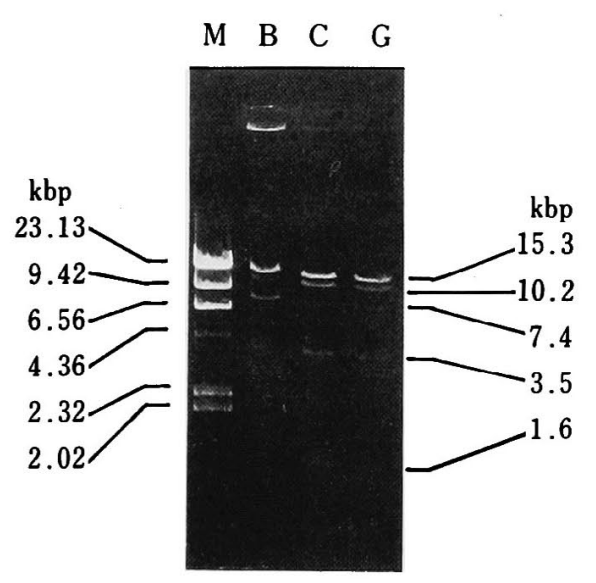

Fig. 3. Agarose-gel electrophoretograms of plasmid samples $\mathrm{B}, \mathrm{C}$ and $\mathrm{G}$ cleaved by Pst I

Lane M : $\lambda$ DNA cleaved with Hind III (molecular size standards)

Lane B : plasmid sample B cleaved by Pst I

Lane $\mathrm{C}$ : plasmid sample $\mathrm{C}$ cleaved by $P$ st I

Lane G : plasmid sample G cleaved by Pst I

with a linear form appeared as sharp electrophoretic bands on the agar gel, all the plasmid samples prepared in this experiment were cleaved by restriction enzymes such as Bam $\mathrm{H} \mathrm{I}$ or Hin d III to make them linear before electrophoresis (Fig. 1). In the plasmid sample B, 3 bands with molecular sizes of 11.8, 7.4 and 3.5 kilobase pairs (kbp) of nucleotides were obtained (Fig. 1-B) when it was treated with
Bam H I. In the hydrolysates of sample B by Eco R I, one spread band with a molecular size larger than $23 \mathrm{kbp}$, which is known to be a closed circular plasmid DNA, and one sharp Eco R I-band of $15.3 \mathrm{kbp}$ which is a linear plasmid DNA were detected. Considering these data, we concluded that two plasmids of 7.4 and $15.3 \mathrm{kbp}$ were contained in sample $\mathrm{B}$ and denoted as pRAB and pRAC, respectively. In the plasmid sample $\mathrm{C}$, two Bam $\mathrm{H}$ I-bands of 11.8 and $3.5 \mathrm{kbp}$ were mainly found and a $7.4 \mathrm{kbp}$ band was just detectable indicating that both plasmids $\mathrm{pRAB}$ and pRAC were present but the content of plasmid $\mathrm{pRAB}$ was considerably reduced. In the plasmid sample $\mathrm{G}$, three bands having a molecular size and intensity identical to those from sample $\mathrm{C}$ were found on the electrophoretogram after being treated with Bam HI. Restriction mapping of the plasmid samples $\mathrm{B}, \mathrm{C}$ and $\mathrm{G}$ was carried out using Bam HI, Puu II, Hin d III, Eco R I and $P$ st $I$ restriction enzymes. In all cases the electrophoretic patterns for each enzyme were identical in the three plasmid samples revealing that the same two plasmids, pRAB and pRAC, are present in all the plasmid samples. Restriction maps are shown in Fig. 2.

Properties of two plasmids from $R$. albus.

As described above, pRAB was significantly 
decreased when $R$. albus was acclimated on cellobiose or glucose. $R$. albus $\mathrm{F}-40 \mathrm{C}$ and F-40 $\mathrm{G}$ required a long lag time to detect their cellulose-utilizing ability; growth only began when they were incubated in the BMC medium at $37^{\circ} \mathrm{C}$ for 2 and 3 days, respectively. Thereafter, the bacterium was repeatedly transfered into fresh BMC medium and gradually, the cellulose-digesting rate was recovered normally. The reacclimated cells of $R$. albus $\mathrm{F}-40 \mathrm{C}$ and $\mathrm{F}-40 \mathrm{G}$ on $\mathrm{BMC}$ exhibited an increased level of pRAB. These results suggest that $\mathrm{pRAB}$ can be amplified in the presence of cellulose as a main carbon source and it is responsible for the cellulose digesting ability of $R$. albus. $\mathrm{pRAB}$ also requires cellulose as a selection pressure.

In the process of determining the restriction sites of pRAC, Pst I did not effectively cleave pRAC, especially that which was isolated from plasmid sample B. The plasmid cleaved at two sites by Pst I and, represented by the positions of molecular sizes 13.7 and $1.6 \mathrm{kbp}$, was present at the highest relative concentration in plasmid sample B compared to sample $\mathrm{C}$ and $\mathrm{G}$ as shown in Fig. 3. The concentrations of the hydrolysis products with molecular sizes of 10.2 and $3.5 \mathrm{kbp}$ were relatively lower in sample B. The Pst I site on the $\mathrm{H} 1$ fragment of $\mathrm{pRAC}$ seems to be cleaved with the most difficulty (data not shown). These results suggest that the high cellulolytic activity of $R$. albus may be related to the modification of pRAC.

For detecting additional functions of $\mathrm{pRAB}$ and pRAC, both plasmids from plasmid sample $B$ were completely cleaved by $B a m \mathrm{HI}$. The DNA fragments thus obtained were ligated into pACYC 184 conferring chloramphenicol resistance. With the resulting chimera plasmids, E. coli HB 101 was transformed, from which a chimera plasmid containing $\mathrm{pRAB}$ and two plasmids containing either B 1 or B 2 fragment from $p R A C$ were isolated. Three transformants each harboring a chimera plas- mid with individual Bam $\mathrm{HI}$ fragments of pRAB or pRAC were isolated and plated on an LB-agar medium. Detection of CMCase activity of the colonies was examined by the CMCcontaining agar method ${ }^{30)}$. A series of similar experiments was repeated with plasmid sample $\mathrm{B}$ using Pst I or Hin d III. However, no CMCase could be detected in any transformant. This indicates that (a) neither pRAB nor pRAC encodes CMCase or (b) transformants could not express CMCase activity.

In conclusion, we isolated 2 novel plasmids from $R$. albus, $\mathrm{pRAB}$ and $\mathrm{pRAC}$, encoding functions for the cellulose utilization ability of $R$. albus. These cellulose utilization functions are clearly important for an adequate $R$, albus growth on cellulosic resources. This report is the first which describes the characterization of plasmids occurring in $R$. albus.

\section{Acknowledgement}

This work was supported in part by a grantin aid for General Research C No. 0156309 from the Ministry of Education, Science and Culture, Japan.

\section{References}

1) TAYA, M., Y. ITo, K. OHMIYA, T. KOBAYASHI and $S$. Shimizu, J. Ferment. Technol., 57 : 178-185. 1970.

2) Taya, M., K. Ohmiya, T. Kobayashi and S. Shimizu, J. Ferment. Technol., $58:$ 463-469. 1980.

3) Taya, M., K. Honma, K. OHMiya, T, Kobayashi and S. SHIMıZU, J. Chem. Eng., $14: 330-335.1981$.

4) ОhмiYa, K., K. Nokura and S. Shmizu, J. Ferment. Technol., 61: 25-30. 1983.

5) Ohmiya, K., M. Shimizu, M. Taya and S. Shimizu, J. Bacteriol., 150 : 407-409. 1982.

6) OhMiYA, K., M. Shirai and S. ShimizU, J. Bacteriol., $161: 432-434,1985$.

7) OhmiYa, K., K. Maeda and S. Shimizu, Carbohydrate Research, 166 : 145-155. 1987.

8) Chen, W., K. OhmiYa, S. Shimizu and H. Kawakami, Appl. Environ. Microbiol., 49 : 211-216. 1985.

9) Chen, W., K. Supanwong, K. Ohmiya, S. Shimizu and H. Kawakami, Appl. Environ. Microbiol., 50 : 1451-1456. 1985.

10) Ohmiya, K., M. Takeuchi, W. Chen, S. Shimizu and H. Kawakami, Appl. Microbiol. Biotechnol., 23 : 274279. 1986.

11) Chen, W., K. OHimiya, S. Shrmizu and H. KaWaKami, 


\title{
Plasmids from Ruminococcus Albus
}

J. Ferment. Technol., $65: 223-226.1987$.

12) Chen, W., K. Ohmiya, S. Shimizu and H. KawaKami, Appl. Environ. Microbiol., 54 : 1254-1257. 1988.

13) Sukhumavasi, J., K. OhmiYa, M. SuWana-Adth and S. Shimizu, J. Ferment. Technol., 62 : 545-550. 1984.

14) Sukhumavasi, J., K. OнmiYa, S. Shimizu and $K$. UENO, Intern. J. Syst. Bacteriol., 38 ; 179-182. 1988.

15) Sukhumavasi, J., K. OhmiYa, M. SuWana-Adth and S. Shimizu, J. Sci. Soc. Thailand, $15:$ 109-120, 1989.

16) Fujino, T., J. Sukhumavasi, K. OhmiYa and $S$. SHimizU, J. Bacteriol., 171 : 4076-4079. 1989.

17) Taya, M., K. OhmiYa, T. Kobayashi and S. Shimizu, J. Ferment. Technol., 61 : 197-199. 1983.

18) Chen, W., K. OhmiYa, S. Shmizu and H. KaWaKami, Appl. Environ. Microbiol., 52 : 612-616. 1986.

19) Chen, W., K. OнmiYA and S. Shimizu, Appl. Environ. Microbiol., 53 : 542-548. 1987.

20) Chen, W., M. Ohmori, K. OhmiYa and S. Shimizu, J. Ferment. Technol., $66: 341-346.1988$.

21) Chen, W., K. OhmiYa and S. Shimizu, Appl. Environ. Microbiol., 54 : 2300-2304. 1988.

22) Chen, W., K. Nagashima, T. Kajino, K. OhmiYa and S. SнimıU, Appl. Environ. Microbiol., 54: 1249-1253. 1988.

23) OhmiYa, K., K. Nagashima, T. Kajino, E. Goto, A. TsuKADA and S. SHIMIzU, Appl. Environ. Microbiol. $54: 1511-1515.1988$.

24) OhmiYa, K., T. Fujino, J. Sukhumavasi and $\mathrm{S}$. SHImizU, J. Bacteriol.; Appl. Environ. Microbiol, 55 : 2399-2402, 1989.

25) OhmiYA, K., T. Kajino, A. Kato and S. Shimizu, J. Bacteriol., 171. 6771-6775. 1989.

26) Champion, K.M., C.T. Helaszek and B.A. White, Can J. Microbiol., 34 ; 1109-1115. 1988.

27) Asmundson, R.V. and W.J. Kelly, Curr. Microbiol, $16: 97-100.1987$.

28) BIRNBIOM, H.C. and J. DOLY, Nucleic Acids Res., 7 : 1513-1523. 1976.

29) Maniatis, T., E.F. Fritsch and J. Sambrook, Molecular cloning : a laboratory manual. Cold Spring Harbor Laboratory. Cold Spring. Harbor. N.Y. 1982.

30) Teather, R.M. and P.J. Wood, Appl. Environ. Microbiol., $43: 777-780.1982$.

\section{Ruminococcus albus のセルロース資化能に 関与する新奇なプラスミド}

\author{
大宮邦雄・星野智恵子・清水祥一 \\ 名古屋大学農学部, 名古屋市 464-01
}

ルーメン由来の嫌気性セルロース分解細菌 Ruminococcus albus 加ら, Birnboim-Doly 法に上 り 2 種のプラスミドを単離した。これらを $\mathrm{pRAB}$ および $\mathrm{pRAC}$ と命名し，各々の制限䣼素地図を作 成した，両プラスミドはボールミルで磨碎したセルロース（BMC），セロビオースあるいはグルコース を主炭菜源とするいずれの培地に R. albus を馴養した場合にも単離された，pRAB（分子量 7.4 kbp）はセロビオースあるいはグルコースを主炭素源とする培地に馿養した場合に著しく隇少した：こ のとき, R. albus のセルロース分解能は活とんど消失していた。 したがって, pRABはR. albus のセルロース分解能を支配していると推定した.

pRAC は BMC を主炭素源とする培地に馴養した場合の方がグルコースやセロビオースを主炭索源 とした場合に比べPstI で著しく分解され䧼くなっていたことから，pRAC あ R. albus のセルロー ス分解能に関与しているるのと考えている．また，pRACを Hin d III あるいは Bam H I で完全分 解したのち，pACYC 184 に組みこみ，これを用いて大腸菌を形質転換し，CMCase 活性を測定した が, いずれの場合にもこの活性を検出できなかった。

以上の結果より，R. albus から単離された 2 種類のプラスミドは $R$. albus のセルロース分解能に 著しく関与していることが判明した。 